\title{
The Impact of Tour Service Performance on Tourist Satisfaction and Behavioral Intentions: A Study of Chinese Tourists in Hong Kong
}

\author{
Andrew Chan* \\ Cathy H. C. Hsu \\ School of Hotel and Tourism Management, The Hong Kong Polytechnic University \\ $\&$ \\ Tom Baum \\ Department of Human Resource Management, University of Strathclyde, Glasgow
}

*Corresponding Author: Andrew Chan, Assistant Professor, School of Hotel and Tourism Management, The Hong Kong Polytechnic University, Hung Hom, Kowloon, Hong Kong; Tel: +852 3400 2297; Fax: +852 2362 9362; Email: andrew.chan@polyu.edu.hk

Cathy H.C. Hsu, Professor and Associate Dean, School of Hotel and Tourism Management, The Hong Kong Polytechnic University, Hung Hom, Kowloon, Hong Kong; Tel: +852 3400 2323; Fax: +852 2362 9362; Email: cathy.hsu@polyu.edu.hk

Tom Baum, Professor, Department of Human Resource Management, University of Strathclyde, Graham Hills Building, 50 Richmond Street, Glasgow G1 1XU, Scotland; Tel: +44 141548 3954; Email: t.g.baum@strath.ac.uk 


\title{
The Impact of Tour Service Performance on Tourist Satisfaction and Behavioral Intentions: A Study of Chinese Tourists in Hong Kong
}

\begin{abstract}
This study proposes and tests a tour service performance framework that assesses the impact of tour service performance on tourists' satisfaction with tour services and experience as well as their behavioral intentions, based on data collected from 580 Chinese tourists participating in package tours in Hong Kong. All of the scales used were pre-tested and refined using confirmatory factor analysis. The results show that satisfaction with tour services and satisfaction with the tour experience are distinct constructs with differential relationships with the various tour services. Among the seven tour services examined, tour guiding service has the greatest impact on satisfaction with tour services, whereas leisure activities have the greatest impact on satisfaction with the tour experience. The results also suggest that behavioral intentions are determined by tour guide service and tourist satisfaction. The methodology employed allows a comprehensive and focused evaluation of all services included in package tours.
\end{abstract}

KEYWORDS. Customer satisfaction, service quality, tour service, tour experience, package tour, behavioral intention. 


\section{INTRODUCTION}

Tourists who participate in package tours are often looking for a total experience, and thus a perceived shortfall in any dimension of a tour can give rise to tourist dissatisfaction or defection. However, the quality of a package tour does not depend on the performance of a single supplier, but is rather the result of the coordinated efforts of many travel suppliers, such as airlines, cruise companies, coach and bus companies, railways, hotels, restaurants, shops, and theme parks, to name just a few. These suppliers often differ in their goals and objectives, and no single organization has direct control over the others. In order to determine whether all or particular parts of tour services actually live up to customer expectations, there is a need to develop methods to assess the performance of individual suppliers of the services included in package tours.

The present study sought to explicate the effect of seven types of tour services (transportation, accommodation, food, attractions, tour guiding, shopping, and recreation, and entertainment activities) on tourists' satisfaction and behavioral intentions. Tour services are further divided into the three broad categories of core, support, and guiding services based on their effects on tourist satisfaction. Specifically, core services encompass transportation, accommodation, and food, which fulfill customers' basic subsistence needs. They are distinct from support services, which stimulate customers' desire to participate in the tour, and include attractions, shopping, and recreation and entertainment activities. A similar distinction was made by Uysal and Noe (2003) between "instrumental" and "expressive" attributes in the context of outdoor recreation. A guiding service is provided by tour guides and tour leaders, who are responsible for monitoring the itinerary and providing immediate support to customers as the tour moves along. Effective guiding service can create interesting experiences for customers, thereby enhancing their satisfaction and retention (Spears \& Rosenbaum, 2012). 
Tourist satisfaction is a complex phenomenon and its evaluation is a similarly complex process that can be studied at various levels. Some researchers, for example, have differentiated between satisfaction with the tourism services and satisfaction with the tourism experience (del Bosque \& San Martin, 2008; Hosany \& Gilbert, 2010; Neal, Sirgy, \& Uysal, 1999). This distinction is important for both managers and researchers, because the two constructs have different foci and determinants. Specifically, a tourist's satisfaction with a service refers to a satisfaction judgment directed toward the service itself, and is driven by the product and service quality of a transaction (Crompton \& Love, 1995). Tourists are satisfied when the service that they receive matches their expectations. In contrast, tourist satisfaction with the service experience refers to the entire consumption experience, which may be influenced by individual factors. Despite the fact that the two constructs can be distinguished conceptually, few attempts have been made to investigate them simultaneously.

Due to its rapid economic development, China has become the fastest-growing outbound travel market in the world. According to the China Tourism Academy (2011), the number of outbound Chinese tourists has increased seventyfold over the past two decades to 70 million. Although some of the barriers to travel have been removed, many mainland Chinese tourists still prefer to travel as part of a group tour (Yu \& Weiler, 2001; Zhang \& Chow, 2004). Despite their significance, the behaviors of Chinese tourists in tour groups and their perceptions of tour services are not well understood. This study separated tour services into discrete components and examined their relative impact on satisfaction and behavioral intentions. Consideration is given to two types of customer satisfaction: satisfaction with tour services and satisfaction with the tour experience. Results will provide essential information to tour operators who design and bundle tour packages for mainland Chinese tourists.

\section{LITERATURE REVIEW}


A considerable body of work in the tourism literature has focused on assessing the performance of a particular type of tour service, yet little has been done to segment tour services into distinct components and examine the individual impact of these components on tourist satisfaction and behavioral intentions. This section, therefore, provides a brief review of tour services, with an emphasis on understanding their components and dimensions.

Previous studies related to customer satisfaction and behavioral intentions are also reviewed to understand their conceptualization and to support the contention that satisfaction with tour services and satisfaction with the tour experience are separate and distinct constructs.

\section{Tour Services}

One of the earliest studies that evaluated tour service performance was conducted by Whipple and Tach (1988), who partitioned a trip to Niagara Falls into tourism services and attractions. Two tourism services factors (tour guide service and convenience of departure points) and one attraction factor (the quality of sightseeing) were identified as the determinants of customer satisfaction and revisit intention. In a destination study by Murphy, Pritchard, and Smith (2000), visitors' perceptions of quality were divided into two components of environment and infrastructure. In another study, Weiermair and Fuchs (1999) divided the service quality of ski resorts into the eight components of food and accommodation, sports activities, animation and culture, transportation, skiing, nature, landscape, and shopping. Similarly, Wang, Hsieh, and Huan (2000) separated a package tour from Taiwan into eight consecutive items comprising pre-tour briefing, airports, hotels, restaurants, coach services, scenic spots, shopping, and optional tours. While there is no consensus among researchers as to how tour services are best partitioned, it is generally agreed that tour services can be divided into distinct components and evaluated separately.

A commonly used approach to measure service performance in the tourism industry is that of Parasuraman, Zeithaml, and Berry (1985), in which service is evaluated along the five 
dimensions of reliability, responsiveness, assurance, empathy, and tangibles. A simpler classification is offered by Gronroos (1984), who identified technical and functional quality as the two fundamental sets of quality dimensions. Technical quality involves what customers actually receive from the service, whereas functional quality refers to the manner in which the service is delivered. In the context of this study, technical quality may relate to the guestrooms in hotels, meals in restaurants, the efficiency of transport, the variety of attractions, and the recreation and entertainment facilities offered, whereas functional quality may refer to the customers' contact with service personnel, including hotel staff, restaurant servers, cabin attendants, and tour bus drivers. This two-dimensional structure provides a parsimonious approach to the measurement of customer evaluation of service performance and is adopted in this study. Other researchers have used a similar approach, but identified the dimensions with different terms. For example, Czepiel, Solomon, Surprenant, and Gutman (1985) stated that service evaluation depends on functional and performancedelivery components, the former referring to the content of the service and the latter to the delivery process.

\section{Customer Satisfaction}

In the tourism literature, the term "satisfaction" has been used rather loosely. Some researchers have equated customer satisfaction with attribute performance; some have used the term to reflect customer satisfaction with the service experience, while others have used it to denote both attribute performance and service experience. A review of the literature reveals that there are three broad categories of satisfaction in the tourism domain: satisfaction with the tour service and experience, satisfaction with the destination, and satisfaction with the tourism experience (Alegre \& Garau, 2011; Chi \& Qu, 2008; del Bosque \& San Martin, 2008; Hosany \& Gilbert, 2010; Huang \& Hsu, 2010; Lee, Jeon, \& Kim, 2011; Prayag, 2009). Studies of tour service and experience are aimed at helping travel firms to improve their 
service offerings, whereas studies on destination satisfaction are macro assessments of destinations designed to contribute to the better marketing and positioning of those destinations. Finally, studies of tourism experience have usually been conducted by leisure scientists who want to ascertain the influence of tourism experiences on life satisfaction.

In an effort to distinguish between the service and experiential dimensions of satisfaction, this study defines satisfaction with tour services as tourists' affective response that results from a cognitive appraisal of the services provided by the tour operator.

Customers feel satisfied when the service received meets their expectations. Satisfaction with the tour experience, in contrast, occurs when the needs and motivations of consumers are fulfilled, and is defined as an affective response to the extent to which tour services fulfill tourist needs. An additional difference is that satisfaction with a service can largely be controlled by the service provider (Baker \& Crompton, 2000), whereas satisfaction with an experience is primarily driven by the involvement and motivations of the customer, which are more difficult to manipulate (Mannell \& Iso-Ahola, 1987). Indirect support for this multifaceted concept of satisfaction can be found in some tourism studies in which service items and experience items are included as measures of tourist satisfaction (see Duke \& Persia, 1996; Geva \& Goldman, 1989; Ross \& Iso-Ahola, 1991). The majority of these studies, however, did not make a clear distinction between them. In one of the few studies that separated service satisfaction from experience satisfaction, Neal et al. (1999) demonstrated that student travelers were able to distinguish between satisfaction with tourism services and satisfaction with the tourism experience.

According to Mannell and Iso-Ahola (1987), tourist experience can be captured through post-hoc evaluations, whereby tourists are asked to assess whether their needs have been met at the end of a trip. This approach assumes that tourists have a clear understanding of their travel needs and motivations and that they can consciously evaluate the extent to 
which their needs are fulfilled. Mannell and Iso-Ahola (1987) argued that this conscious reflection would be remembered by tourists and become part of their experience. The main benefit of this approach is that experience can be assessed using current motivation frameworks. As an exploratory study, and in the absence of a consensus on the domain and structure of the tourism experience, this study adopts the parsimonious motivation framework proposed by Mannell and Iso-Ahola (1987), who postulated that tourists are driven by two opposite but complementary goals. On the one hand they want to "escape" from daily routine, but on the other they "seek" psychological (intrinsic) rewards.

\section{Behavioral Intentions}

Behavioral intentions have been conceptualized and measured in many ways and in various contexts. Oliver (1997), for example, identified two types of intention: that with short-term consequences and that with long-term. Word of mouth, complaining or complimenting, and recommendations are regarded as short-term behavioral consequences, whereas loyalty is regarded as a long-term behavioral consequence. There is ample evidence to suggest that satisfied customers are more likely to make the same choice again and also that they bring in new business through positive word of mouth (Rust, Zahorik, \& Keiningham, 1995). Lee, Jeon and Kim (2011), for instance, found that customer satisfaction with tour services was associated with loyalty. In a destination study, Prayag (2009) found that satisfied tourists were more likely to return. Likewise, Zeithaml, Berry, and Parasuraman (1996) found that satisfied customers displayed a greater price tolerance for their usual brands.

In a seminal study, Zeithaml et al. (1996) identified five types of behavioral consequences: loyal to the company, willingness to pay more, propensity to switch, external responses, and internal responses. Loyal to the company and willingness to pay more were found to be the key benefits of customer loyalty. Baker and Crompton (2000) adapted the scale proposed by Zeithaml et al. to examine the perceptions of festival tourists and 
confirmed that better perceptions of festival performance led to greater customer satisfaction, which in turn increased customer loyalty and willingness to pay more. Following the work of Zeithaml et al., and Baker and Crompton, this study conceptualizes behavioral intention as a two-dimensional construct that covers loyalty and willingness to pay more.

\section{RESEARCH MODEL}

The research model presented in Figure 1 includes seven tour services: attractions, recreation and entertainment, shopping, tour guiding service, food, transportation, and accommodation. As food, transportation, and accommodation are fundamental to subsistence, they are referred to as core services. Attractions, recreation and entertainment, and shopping are intended to stimulate customers' desire to participate in the tour, and are thus referred to as support services. Guiding services in this case is the service provided by tour guides.

Satisfaction with tour services refers to customers' evaluation of the services provided by the tour operator, where customers are deemed to be satisfied if their expectations of the service aspects are met. Following Mannell and Iso-Ahola (1987), satisfaction with the tour experience is conceptualized as a two-dimensional construct that includes seeking and escaping, and is assumed to be an affective response to the extent to which the tour services fulfill customer needs for escape and adventure. If these needs are met, a high level of satisfaction with the tour experience will result. Behavioral intentions are consumers' subjective probabilities of participating in tours organized by a tour operator and their willingness to pay.

\section{$<$ Insert Figure 1 Here $>$}

\section{Hypotheses}

Satisfaction with tour services was hypothesized to be related to seven types of tour services based on previous research that treated satisfaction as something that emerges from the 
services themselves (LeBlanc, 1992; Prayag, 2009). Customer satisfaction with tour services is posited to result when customers' expectations are met and the tour services are considered "good value for money". The following hypothesis is therefore proposed.

H1: A higher level of tour service performance leads to a higher level of tourist satisfaction with the services of package tours.

Support and guiding services are the prime motives for participating in tours. When these services are perceived to offer experiences that meet customers' needs, a high level of satisfaction with the tour experience will result. Although core services such as transportation and accommodation are essential in tours, they are not ends in themselves. Customers would not be satisfied with the tour experience if the core services were good but the support services were boring. Thus, it is reasonable to assume that satisfaction with the tour experience is predominantly driven by the support and guiding services. The rationale is similar to Herzberg's two-factor theory (Herzberg, 1966), where the presence of hygiene factors does not necessarily lead to job satisfaction. The core services of a tour can be considered as hygiene factors that serve only to prevent customers from being dissatisfied with the tour experience (Balmer \& Baum, 1993; Johnston, 1995). Support and guiding services are deemed to be motivators that stimulate consumer interest in the tour. Some support for this relationship can be found in the literature. For example, Mannell and IsoAhola (1987) singled out activities as key influences on leisure experience, and Lounsbury and Hoopes (1985) found that vacation satisfaction was predominantly affected by vacation activities and experience. Based on these conceptual analyses and empirical support, the following hypothesis is proposed.

H2: A higher level of support and guiding service performance leads to a higher level of tourist satisfaction with the experience of package tours. 
Satisfaction with tour services is generally considered to be an antecedent of satisfaction with the tour experience. Tour services that meet or exceed customer expectations should trigger a high level of satisfaction with the tour experience. Customers who cannot obtain what they want from the various tour suppliers are likely to have a negative tour experience. Empirical support for this notion can be found in Neal et al. (1999), who reported that satisfaction with travel and tourism services was positively related to satisfaction with the travel and tourism experience. Cadotte, Woodruff, and Jenkins (1987) similarly found that customer satisfaction directly influenced dining experience, and Oliver (1993) demonstrated that satisfaction was significantly related to positive affect (joy and interest), a construct that has similarities with the construct of satisfaction with the tour experience. Thus, the following hypothesis is advanced concerning the relationship between satisfaction with tour services and satisfaction with the experience of package tours.

H3: A higher level of tourist satisfaction with tour services leads to a higher level of tourist satisfaction with the experience of package tours.

The two satisfaction constructs examined in this study are believed to have a significant impact on behavioral intentions. Specifically, a high level of satisfaction with tour services is expected to lead to a positive attitude toward the tour operator, which is in turn directly related to the future purchase of vacation packages from that operator. Similarly, a pleasurable tour that satisfies a tourist's needs is more likely to lead to the continued engagement of the operator for future tours than a dissatisfying tour. This view corresponds with Fishbein and Ajzen's attitude-behavior model (1974), which postulates that a favorable attitude leads to the intention to repurchase. Thus, the following hypotheses were tested.

H4a: A higher level of tourist satisfaction with tour services leads to a higher level of behavioral intentions toward the tour operator. 
H4b: A higher level of customer satisfaction with the tour experience leads to a higher level of behavioral intentions toward the tour operator.

\section{RESEARCH DESIGN}

\section{Measurement}

\section{$\underline{\text { Tour service performance }}$}

To develop a better understanding of the underlying constructs that constitute tour services, four focus groups were conducted among residents in Beijing who had joined a package tour to Hong Kong in the previous 12 months. The groups ranged in size from six to eight members each and represented a variety of ages and occupations. The discussions were audio-recorded and all participants were promised confidentiality. Participants were asked questions about their reasons for joining package tours, experience and satisfaction with various tour services, and critical experiences during the tour. Focus group transcriptions in Chinese were coded and their content analyzed by two researchers. Open coding was used to identify tour service themes and domains. Thirty items were generated to cover the seven types of tour services; that is, attractions, recreation and entertainment, shopping, tour guiding service, food, transportation, and accommodation. The aim of these items was to capture the technical and functional domains suggested by Gronroos (1984). Items were rated on a five-point Likert-type scale ranging from 1 (very poor service) to 5 (very good service).

\section{$\underline{\text { Satisfaction with tour services }}$}

Tourist satisfaction with tour services was measured by three items adapted from Crosby and Stephens' (1987) satisfaction scale. Respondents rated items on three 7-point scales, with a higher score representing a more positive response. The endpoints of the three items were “dissatisfied/satisfied," “displeased/pleased," and "unfavorable/favorable," respectively. This scale has been referenced in many studies, and has demonstrated good validity and a stable 
reliability in several populations (Oliver, 1993; Oliver \& Swan, 1989). Crosby and Stephens (1987) reported a reliability coefficient of .96 and Baker and Crompton (2000) found a coefficient alpha of .98 .

\section{$\underline{\text { Satisfaction with the tour experience }}$}

Six items were adapted from three previous studies (Otto \& Ritchie, 1996; Price, Arnould, \& Tierney, 1995; Ross \& Iso-Ahola, 1991) to represent the "seek" and "escape" dimensions of the tour experience. Seek and escape were both measured by three items. Respondents rated each item on a five-point Likert-type scale ranging from 1 (strongly disagree) to 5 (strongly agree).

\section{$\underline{\text { Behavioral intentions }}$}

Behavioral intentions were measured by four items adapted from a scale developed by Zeithaml et al. (1996). The scale consists of two items on loyalty and two items on willingness to pay. A five-point scale was used, with 1 representing "very unlikely" and 5 “very likely.” Baker and Crompton (2000) reported alphas of 0.88 and 0.77 for loyalty and willingness to pay subscales, respectively.

Before the full-scale survey, a pilot test was conducted with 180 mainland Chinese tourists at three tourist spots in Hong Kong. Face-to-face interviews were used to allow the interviewer to ascertain whether the respondents fully understood the items and wording. Respondents were asked to assess the performance of tour services that they had experienced. Their satisfaction level and behavioral intentions were also collected. The pilot test data were analyzed using coefficient alphas and item-total correlations. Five items in the tour service performance scale were dropped because of low item-total correlations (correlation coefficients $<0.3$ ). All other items had an item-total correlation of above 0.3 , and were thus retained. All scales yielded high coefficient alphas, ranging from 0.84 to 0.91 . 
Two exploratory factor analyses were conducted to examine the underlining structure of the remaining items, one for the tour service items and the other for the customer satisfaction and behavioral intention items. The use of separate factor analyses is recommended when "prediction or causation can be assumed from one domain to another on the basis of external information" (Gorsuch, 1983, p. 281). Given that causal relationships are being hypothesized, two separate factor analyses were performed. The first factor analysis consisted of 25 items pertaining to the seven types of tour services. The results supported the existence of a seven-factor solution. Four items, however, did not load on any factor and were deleted. All seven factors yielded very high coefficient alphas, ranging from 0.75 to 0.91 . The second factor analysis contained 13 items, and was related to customer satisfaction and behavioral intentions. All of the items loaded into their respective factors and no item was deleted. The coefficient alphas of all factors exceeded 0.7 , indicating acceptable reliability. The final instrument consisted of four scales measuring tour service performance (21 items), satisfaction with tour services (three items), satisfaction with tour experience (six items), and behavioral intentions (four items).

\section{Data Collection}

The targeted sample included mainland Chinese tourists who visited Hong Kong in a tour group and experienced various tour services. Chinese tourists participating in package tours were approached at three popular tourist spots in Hong Kong over a two-week period. A quota sampling method was used to obtain a sample that was broadly representative of Chinese tourists visiting Hong Kong based on the demographic profile reported by the Hong Kong Tourism Board. Respondents were assigned to three age groups: young, 16-35 (49\%), middle-aged, 36-55 (42\%), and old, 56 and over (9\%). Across each of the age groups, the ratios of male-to-female and married-to-single were 1:1 and 4:1, respectively. Those who matched the age, gender, and marital status criteria and consented to participate were given a 
copy of the questionnaire and a self-addressed pre-paid return envelope. They were asked to complete the survey at the end of the tour and return it to the researcher by post. As an incentive, respondents who identified themselves were offered the chance to be included in a lottery for $20 \mathrm{RMB} \$ 100$ prizes. The questionnaire items were originally in Chinese and were translated into English for publication.

\section{RESULTS}

Of the 1,200 questionnaires distributed, 580 usable copies were returned, giving a response rate of $48.3 \%$. Table 1 shows the demographic profiles of the respondents. Of the 580 respondents, $40.7 \%$ were male and $59.3 \%$ female. A high percentage $(29.0 \%)$ belonged to the 26-35 age group, and the overwhelming majority (75.5\%) were married. In general, the sample obtained closely mirrors the general population in terms of age, gender, and marital status (HKTB, 2007). Most of the respondents were either secondary school graduates $(24.8 \%)$ or college graduates $(64.7 \%)$. About one-third of the respondents $(33.6 \%)$ came from Eastern China, 19.5\% came from Northern China, 13.4\% came from Central China, and $10.0 \%$ came from Southwestern China. Over one-third of the respondents (34.1\%) reported a monthly household income of between RMB2,000 and RMB3,999, and another 21.6\% had an income between RMB4,000 and RMB5,999. Nearly one in six (16.5\%) had an income RMB1,999 or below, and more than 7\% had an income of RMB12,000 or above. Most of the respondents (72.2\%) had never traveled to Hong Kong before.

\section{$<$ Insert Table 1 Here $>$}

\section{Measurement model}

A confirmatory factor analysis was conducted to assess the construct validity of the tour service performance scale. Diagonally weighted least squares (DWLS) estimation was used because the scales are ordinal in nature (Flora \& Curran, 2004). An initial seven-factor model 
was tested, but the results indicated a less than adequate fit $\left(\chi^{2}=562.56, \mathrm{df}=168, \mathrm{p}<.001\right.$, standardized RMR $=.09, \mathrm{RMSEA}=.09, \mathrm{CFI}=.93, \mathrm{NNFI}=.93)$. Modification indices revealed that the items for attractions and recreation and entertainment cross-loaded, which implied that they might belong to the same factor. Two items from attractions and one item from recreation and entertainment were dropped and the two factors were thus combined into a single factor, "leisure activities."

The revised model produced better fit indices $\left(\chi^{2}=354.26, \mathrm{df}=120, \mathrm{p}<.000\right.$, standardized $\mathrm{RMR}=.057, \mathrm{RMSEA}=.059, \mathrm{CFI}=.99, \mathrm{NNFI}=.98)$. Although the chi-square statistic was significant, all other model fit indices provided evidence of a good model fit. Table 2 presents the factor loadings, composite reliability, and variance extracted for the scales. All factor loadings were close to or above .70, demonstrating strong convergent validity. The composite reliability ranged from .85 to .92 , and all coefficients were within the recommended minimum range (Fornell \& Larcker, 1981). Pair-wise comparisons showed changes in the chi-square statistics between the constrained and unconstrained conditions that were significant at levels below $\mathrm{p}<.0001$, indicating strong discriminant validity.

\section{<Insert Table 2 Here $>$}

Another confirmatory factor analysis was performed on the satisfaction and behavioral intentions scales. Specifically, satisfaction with the tour experience was specified as a second-order construct made up of two first-order constructs: seeking and escaping. Similarly, behavioral intention was a second-order construct related to two first-order constructs: willingness to pay and loyalty. Results indicated that the model fit the data reasonably well $\left(\chi^{2}=177.80, \mathrm{df}=60, \mathrm{p}<.001\right.$, standardized $\mathrm{RMR}=.029, \mathrm{RMSEA}=.045$, $\mathrm{CFI}=.98, \mathrm{NNFI}=.94)$. One item from "seeking", however, cross-loaded on another factor and was deleted. The revised measurement model produced a clear factor structure and improvement in all fit indices $\left(\chi^{2}=95.80, \mathrm{df}=49, \mathrm{p}<.01\right.$, standardized $\mathrm{RMR}=.019, \mathrm{RMSEA}$ 
$=.041, \mathrm{CFI}=.99, \mathrm{NNFI}=.99)$. Compared with the initial model, the revised model had 11 fewer degrees of freedom, and its chi-square value was 82 lower. As a significant reduction of chi-square was obtained $\left(\chi^{2}=82, \mathrm{df}=11, \mathrm{p}<.001\right)$, it can be concluded that the revised model fits the data better (Bagozzi, 1980).

As shown in Table 3, all factor loadings were above .70, providing strong support for convergent validity. The composite reliability ranged from .93 to .98 , all within the recommended range (Fornell \& Larcker, 1981). All pair-wise comparisons showed changes in chi-square statistics between constrained and unconstrained conditions that were significant at levels below $\mathrm{p}<.0001$, thus indicating strong discriminant validity.

\section{$\underline{\text { Structural model }}$}

The two second-order constructs (satisfaction with the tour experience and behavioral intentions) were first transformed into first-order constructs using a partial aggregation technique. This method produces a more parsimonious model and reduces random error (Bagozzi \& Edwards, 1998). The items for "seeking" and "escaping" were combined to serve as indicators of satisfaction with tour experience, and the same approach was applied to behavioral intentions. Consequently, satisfaction with tour service and behavioral intentions were represented by two combined indicators each.

The proposed model was tested on the transformed data. The fit statistics indicated that the initial model fit the data to some extent $\left(\chi^{2}=924.03, \mathrm{df}=378, \mathrm{p}<.00\right.$, standardized $\mathrm{RMR}=.086, \mathrm{RMSEA}=.05, \mathrm{CFI}=.99, \mathrm{NNFI}=.98)$. An examination of the modification indices suggested that an improvement in the overall fit of the model could be achieved by allowing tour guiding service to also predict behavioral intentions, and this path was thus added to the model. The final model demonstrated an adequate fit $\left(\chi^{2}=875.02, \mathrm{df}=377, \mathrm{p}<\right.$ .000 , standardized RMR $=.061, \mathrm{RMSEA}=.048, \mathrm{CFI}=.99, \mathrm{NNFI}=.98)$. Although the chi- 
square statistic was significant, the ratio of the chi-square value to the degrees of freedom was within the acceptable range (Marsh, 1988).

The final model is shown in Figure 2, with solid lines indicating path coefficients that are significant at the 0.05 level and an alternating dot/dash line indicating the significant relationship that was not hypothesized in the initial model. The finding that tour guiding service had a direct effect on behavioral intentions is understandable. When customers feel that their holiday has been enhanced by the tour guide's encouragement and engagement, they are more likely to participate in another tour with the same tour operator. Zeithaml et al. (1996) similarly found that customer behavioral intentions were affected by the behavior of the person who was delivering the service, and that customer loyalty tended to increase when the service providers were friendly and approachable.

The first hypothesis posited that the performance of tour services would have a significant positive effect on customer satisfaction with tour services. Path analysis results showed that the effects of leisure activities, shopping, and tour guiding service were significant, whereas those of all core services (transportation, accommodation, and food) were insignificant. These results seemed to contradict the common belief that core components are important to tourists, and that perceptions of core service performance constitute a large part of customer satisfaction. The results instead suggested that core services have become commodities that differ little across the industry. That is, they form the defensive component of a tour: an element that is necessary to keep customers from being dissatisfied, but that will not itself create satisfaction (Johnston, 1995). Danaher and Arweiler (1996) and Hsu (2000) found similar results among tourists in New Zealand and the United States. In this study, customer satisfaction with tour services was mainly driven by tour guide service $\left(\gamma_{1,6}=.38\right)$, shopping $\left(\gamma_{1,4}=.23\right)$, and leisure activities $\left(\gamma_{1,3}=.12\right)$, which together accounted for $40 \%$ of the variance in customer satisfaction with tour services. 


\section{$<$ Insert Figure 2 Here $>$}

The second hypothesis proposed that the performance of support and guiding services would have a positive influence on customer satisfaction with the tour experience. The results presented in Figure 2 indicated that all the hypothesized relationships were supported. The standardized coefficients were .26 for leisure activities, .13 for shopping, and .21 for tour guiding service, implying that leisure activities played a more significant role in customer satisfaction with the tour experience. Overall, these tour services accounted for $53 \%$ of the variance in satisfaction with the tour experience.

The results also provided support for the third hypothesis, as customer satisfaction with tour services had a statistically significant positive effect on customer satisfaction with the tour experience $\left(\beta_{2,1}=.27\right)$. One of the arguments put forward earlier was that satisfaction with tour services and satisfaction with the tour experience represent two empirically distinct constructs in package tours. Results of the confirmatory factor analysis showed that it was indeed possible to separate them this way.

The fourth hypothesis proposed that customer satisfaction with tour services and the tour experience would positively influence customer behavioral intentions. The results demonstrated that both satisfaction with tour services and satisfaction with the tour experience had a significant impact on customer behavioral intentions, explaining more than $52 \%$ of the variation in this construct. The impact of satisfaction with the tour experience $\left(\beta_{4,2}\right.$ $=.11)$ was slightly stronger than that of satisfaction with tour services $\left(\beta_{4,3}=.10\right)$.

\section{DISCUSSION AND CONCLUSION}

\section{Academic Contributions}

This study makes two major academic contributions. First, the methodology employed herein affords a comprehensive and focused evaluation of all the services included in a package 
tour. The division of tour services into components helps to pinpoint the salient elements of tours and identify areas for further improvement. This contributes to current tourism research as the majority of previous studies focused on a specific service component such as hotel services (Slevitch \& Oh, 2010), restaurant services (Han \& Ryu, 2009), and travel agency services (LeBlanc, 1992). For example, tour guide performance was the focus of a study by Huang, Hsu, and Chan (2010), who developed a scale for evaluating the tour guide performance in Shanghai. A unique feature of the hospitality and tourism sector is that services are provided by a variety of service suppliers. Many tourism organizations, such as destination marketing organizations, meeting planners, and event organizers, should therefore benefit from the proposed approach as they are required to monitor the performance of a wide range of service suppliers.

The finding that satisfaction with tour services is different from satisfaction with the tour experience is another contribution. Previous marketing and tourism research has either not explored the experiential aspect or has combined it with service satisfaction. Although the two constructs may be related, the importance of their various antecedents and their consequences may differ. It may thus make more sense to treat them as separate constructs and to develop measures for assessing them independently. Given that experience is also affected by individual psychological factors such as mood or emotion, some people may question the value of research that examines the consumption experience, especially in the case of physical products over which marketers have no control in terms of how and where they are used. However, tour services are consumed in a planned and organized manner, and operators have the opportunity and responsibility to design packages that maximize the customer experience and customer enjoyment. Thus, further research on tourist experience is necessary to understand its causes and consequences.

\section{Professional Implications}


This study developed a quantitative questionnaire to measure tour services in package tours, an instrument which could be administrated periodically to monitor the quality of services that are provided by different tourism suppliers. Such monitoring is important because each service component has a differential effect on customer satisfaction and behavioral intentions. Support and guiding services were identified in this study as having the greatest effect on customer satisfaction, whereas the effect of core services was negligible. In Hong Kong, competition in the tourism sector has been based on the provision of core services, such as hotels, airlines, and restaurants. Deluxe hotels, direct flights, and brand new tour buses are often featured in holiday brochures and advertisements, and many tour operators believe that they are selling tour itineraries rather than experiences. However, with the increasingly fierce competition in the sector many core services have become commodities. Holidaymakers on tours that are organized by different operators may well end up traveling on the same flights, staying in the same hotels, and visiting the same attractions. To make matters worse, price is the major point of competition, and securing a greater market share is the prime goal of many operators. Unfortunately, price and market share will not provide a winning edge when the market becomes more individualized and consumers become more demanding. More resources should therefore be devoted to support and guiding services to facilitate customers' satisfaction with tour experience. This is not to suggest that core services and prices are unimportant, merely that they may not carry the same weight as support and guiding services.

Tour operators now need to focus more on tour experience as a means of product differentiation. They should sell on the basis of the experience offered rather than on price, and should consider themselves as "experience providers." The escaping and seeking dimensions in particular should be emphasized in program design. For example, appropriate free time could be scheduled to allow customers relax and unwind. Operators in Hong Kong tend to include many attractions and activities to ensure that the tours are perceived as value 
for money, and to attract a diverse customer base. It is not uncommon for a tour to visit five or six attractions a day, regardless of whether their customers actually enjoy this.

Additionally, special activities, local festivals, and events could be arranged to add novelty and excitement to tours. After all, it is the unpredictable events that make a tour exciting and memorable (Bowen, 2001). These efforts are of great importance given the significant relationship between satisfaction with tour experience and behavioral intentions.

Of all the tour services examined in this study, tour guiding service had the greatest effect on satisfaction with tour services and the second greatest effect on satisfaction with the tour experience. It also had a direct effect on behavioral intentions. Despite this, in Hong Kong, tour guides are the industry's lowest-paid and least-trained employees (Au, 1998). They receive a basic salary but rely on gratuities for the bulk of their income, and many receive little training before they actually lead a tour. The lack of compensation and training has led to a high turnover rate and low morale (Ap \& Wong, 2001). Given the important role that tour guides play in enhancing customer satisfaction and favorable behavioral intentions, tour operators should consider offering better compensation packages and training to their tour guides.

\section{Limitations and Further Studies}

Some limitations of this study must be noted along with its findings. First, results were obtained from mainland Chinese tourists visiting Hong Kong in group tours. Chinese tourists may have specific interests and motivations that affect their behavior. The results from this study will thus not necessarily generalize to other tourist groups or destinations. Another limitation is that the measurement model was assessed by two confirmatory factor analyses. A single confirmatory factor analysis could have been used instead to avoid capitalizing on chance (Gorsuch, 1983, p. 153). Furthermore, the structure model was modified by transforming the satisfaction and behavioral constructs into first-order constructs. While this 
approach can reduce random error, it does not make full use of the data available. Had the constructs been modeled as second-order constructs, more precise estimates of the relationships could have been obtained.

Several areas emerge from this study that should be addressed in future research. First, although the measurement of tour service performance presented here shows promise, validation in other contexts is necessary to establish its overall usefulness. Second, measures of satisfaction with the tour experience would be a major contribution to the tourism literature. In this study, customer satisfaction with the tour experience was conceptualized as a two-dimensional construct comprising the components of "seek" and "escape." Although most travel needs and motivations are covered by this broad definition, more specific measures could be developed to reflect more subtle travel experience. Case studies and field observations could also be initiated to provide a more detailed and insightful understanding of the tour experience. Finally, other variables that may affect customer satisfaction, including customer motivation, personality, and previous travel experience, could be explored by future research. 


\section{REFERENCES}

Alegre, J., \& Garau, J. (2011). The factor structure of tourist satisfaction at sun and sand destinations. Journal of Travel Research, 50(1), 78-86.

Ap, J., \& Wong, K. (2001). Case study on tour guiding: Professionalism, issues and problems. Tourism Management, 22(5), 551-563.

Au, K. (1998). Tour guides face licensing scheme. Varsity, 43(May), 9.

Bagozzi, R. P. (1980). Causal models in marketing. New York: John Wiley \& Sons.

Bagozzi, R. P., \& Edwards, J. R. (1998). A general approach for representing constructs in organizational research. Organizational research methods, 1(1), 45-87.

Baker, D. A., \& Crompton, J. L. (2000). Quality, satisfaction and behavioural intentions. Annals of Tourism Research, 27(3), 785-804.

Balmer, S., \& Baum, T. (1993). Applying Herzberg's hygiene factors to the changing accommodation environment. International Journal of Contemporary Hospitality Management, 5(2), 32-35.

Bowen, D. (2001). Antecedents of consumer satisfaction and dissatisfaction (CS/D) on longhaul inclusive tours - a reality check on theoretical considerations. Tourism Management, 22, 49-61.

Cadotte, E. R., Woodruff, R. B., \& Jenkins, R. L. (1987). Expectations and norms in models of consumer satisfaction. Journal of Marketing Research, 24(3), 305-314.

Chi, C., \& Qu, H. (2008). Examining the structural relationships of destination image, tourist satisfaction and destination loyalty: An integrated approach. Tourism Management, $29(4), 624-636$.

China Tourism Academy. (2011). Blue book of China's tourism economy (No. 4) - China's tourism performance: Review and forecast (2011-2012). China Tourism Press. 
Crompton, J. L., \& Love, L. L. (1995). The predictive validity of alternative approaches to evaluating quality of a festival. Journal of Travel Research, 34(1), 11-24.

Crosby, L. A., \& Stephens, N. (1987). Effects of relationship marketing on satisfaction, retention, and prices in the life insurance industry. Journal of Marketing Research, 24, 404-11.

Czepiel, J. A., Solomon, M. R., Surprenant, C. F., \& Gutman, E. G. (1985). Service encounters: An overview. In J. A. Czepiel, M. R. Solomon \& C. F. Surprenant (Eds.) The service encounter: Managing employee/customer interaction in service business (pp. 3-15). Lexington, MA: D. C. Heath and Company.

Danaher, P. J., \& Arweiler, N. (1996). Customer satisfaction in the tourist industry: A case study of visitors to New Zealand. Journal of Travel Research, 35, 89-93.

del Bosque, I., \& San Martin, H. (2008). Tourist satisfaction: A cognitive-affective model. Annals of Tourism Research, 35(2), 551-573.

Duke, C. R., \& Persia, M. A. (1996). Consumer-defined dimensions for the escorted tour industry segment: Expectations, satisfactions, and importance. Journal of Travel \& Tourism Marketing, 5(1), 77-99.

Fishbein, M., \& Ajzen, I. (1974). Attitudes towards objects as predictors of single and multiple behavioural criteria. Psychological Review, 81(1), 29-74.

Flora, D. B., \& Curran, P. J. (2004). An empirical evaluation of alternative methods of estimation for confirmatory factor analysis with ordinal data. Psychological Methods, $9(4), 466-491$.

Fornell, C., \& Larcker, D. F. (1981). Evaluating structural equation models with unobservable variables and measurement error. Journal of Marketing Research, 18(3), $39-50$. 
Geva, A., \& Goldman, A. (1989). Changes in the perception of a service during its consumption: A case of organised tours. European Journal of Marketing, 23(12), 4452.

Gorsuch, R. L. (1983). Factor Analysis. New York: Lawrence Erlbaum.

Gronroos, C. (1984). A service quality model and its marketing implications. European Journal of Marketing, 18(4), 36-44.

Han, H., \& Ryu, K. (2009). The roles of the physical environment, price perception, and customer satisfaction in determining customer loyalty in the restaurant industry. Journal of Hospitality \& Tourism Research, 33(4), 487-510.

Herzberg, F. (1966). Work and the nature of man. Cleveland, OH: World.

HKTB. (2007). 2007 visitor profile report. Hong Kong Tourism Board.

Hosany, S., \& Gilbert, D. (2010). Measuring tourists' emotional experiences toward hedonic holiday destinations. Journal of Travel Research, 49(4), 513-526.

Huang, J., \& Hsu, C. (2010). The impact of customer-to-customer interaction on cruise experience and vacation satisfaction, Journal of Travel Research, 49(1), 79-92.

Huang, S., Hsu, C., \& Chan, A. (2010). Tour guide performance and tourist satisfaction: A study of the package tours in Shanghai. Journal of Hospitality \& Tourism Research, 34(1), 3-33.

Hsu, C. H. (2000). Determinants of mature travellers' motorcoach tour satisfaction and brand loyalty. Journal of Hospitality \& Tourism Research, 24(2), 223-238.

Johnston, R. (1995). The determinants of service quality: Satisfiers and dissatisfiers. International Journal of Service Industry Management, 6(5), 53-71.

Lee, S., Jeon, S., \& Kim, D. (2011). The impact of tour quality and tourist satisfaction on tourist loyalty: The case of Chinese tourists in Korea. Tourism Management, 32, $1115-1124$. 
LeBlanc, G. (1992). Factors affecting customer evaluation of service quality in travel agencies: An investigation of customer perceptions. Journal of Travel Research, $30(4), 10-16$.

Lounsbury, J. W., \& Hoopes, L. L. (1985). An investigation of factors associated with vacation satisfaction. Journal of Leisure Research, 17(1), 1-13.

Mannell, R. C., \& Iso-Ahola, S. E. (1987). Psychological nature of leisure and tourism experience. Annals of Tourism Research, 14, 314-333.

Marsh, H.W. (1988). Goodness-of-fit indexes in confirmatory factor analysis: The effect of sample size. Psychological Bulletin, 103(3), 391-410.

Murphy, P., Pritchard, M., \& Smith, B. (2000). The destination product and its impact on traveler perceptions. Tourism Management, 21, 43-52.

Neal, J. D., Sirgy, M. J., \& Uysal, M. (1999). The role of satisfaction with leisure travel/tourism services and experience in satisfaction with leisure life and overall life. Journal of Business Research, 44, 153-163.

Oliver, R. L. (1993). Cognitive, affective, and attribute based of the satisfaction response. Journal of Consumer Research, 20, 418-430.

Oliver, R. L. (1997). Satisfaction: A behavioral perspective on consumer. New York: McGraw-Hall.

Oliver, R. L., \& Swan, J. E. (1989). Consumer perceptions of interpersonal equity and satisfaction in transactions: A field survey approach. Journal of Marketing, 53, 21-35.

Otto, J. E., \& Ritchie, J. R. (1996). The service experience in tourism. Tourism Management, $17(3), 165-174$.

Parasuraman, A., Zeithaml, V. A., \& Berry, L. L. (1985). A conceptual model of service quality and its implications for future research. Journal of Marketing, 49(4), 41-50. 
Prayag, G. (2009). Tourist's evaluations of destination image, satisfaction, and future behavioral intentions: The case of Mauritius. Journal of Travel \& Tourism Marketing, 26(8), 836-853.

Price, L., Arnould, E., \& Tierney, P. (1995). Going to extremes: Managing service encounters and assessing provider performance. Journal of Marketing, 59(April), 83-97.

Ross, E. L., \& Iso-Ahola, S. E. (1991). Sightseeing tourists' motivation and satisfaction. Annuals of Tourism Research, 18, 226-237.

Rust, R. T., Zahorik, A. J., \& Keiningham, T. L. (1995). Return on quality (ROQ): Making service financially accountable. Journal of Marketing, 59, 58-70.

Slevitch, L., \& Oh, H. (2010). Asymmetric relationship between attribute performance and customer. International Journal of Hospitality Management, 29, 559-569.

Spears, D., \& Rosenbaum, M. (2012). The packaged tourist: A Japanese and American perspective. Tourismos: An International Multidisciplinary Journal of Tourism, 7(1), $19-40$.

Uysal, M., \& Noe, F. (2003). Satisfaction in outdoor recreation and tourism settings. In E. Laws (Ed.) Case Studies in Tourism Marketing. London: Continuum.

Wang, K., Hsieh, A., \& Huan, T. (2000). Critical service features in group package tour: An exploratory research. Tourism Management, 21, 177-189.

Weiermair, K., \& Fuchs, M. (1999). Measuring tourist judgment on service quality. Annals of Tourism Research, 26(4), 1004-1021.

Whipple, T. W., \& Tach, S. V. (1988). Group tour management: Does good service produce satisfied customers? Journal of Travel Research, 27(2), 16-21.

Yu, X., \& Weiler, B. (2001) Mainland Chinese pleasure travelers to Australia: A leisure behavior analysis. Tourism, Culture \& Communication, 3, 81-91. 
Zeithaml, V. A., Berry, L. L., \& Parasuraman, A. (1996). The behavioural consequences of service quality. Journal of Marketing, 60 (April), 31-46.

Zhang, H.Q., \& Chow, I. (2004). Application of importance-performance model in tour guides' performance: Evidence from mainland Chinese outbound visitors in Hong Kong. Tourism Management, 25, 81-91. 


\section{Figure 1: Proposed Model}

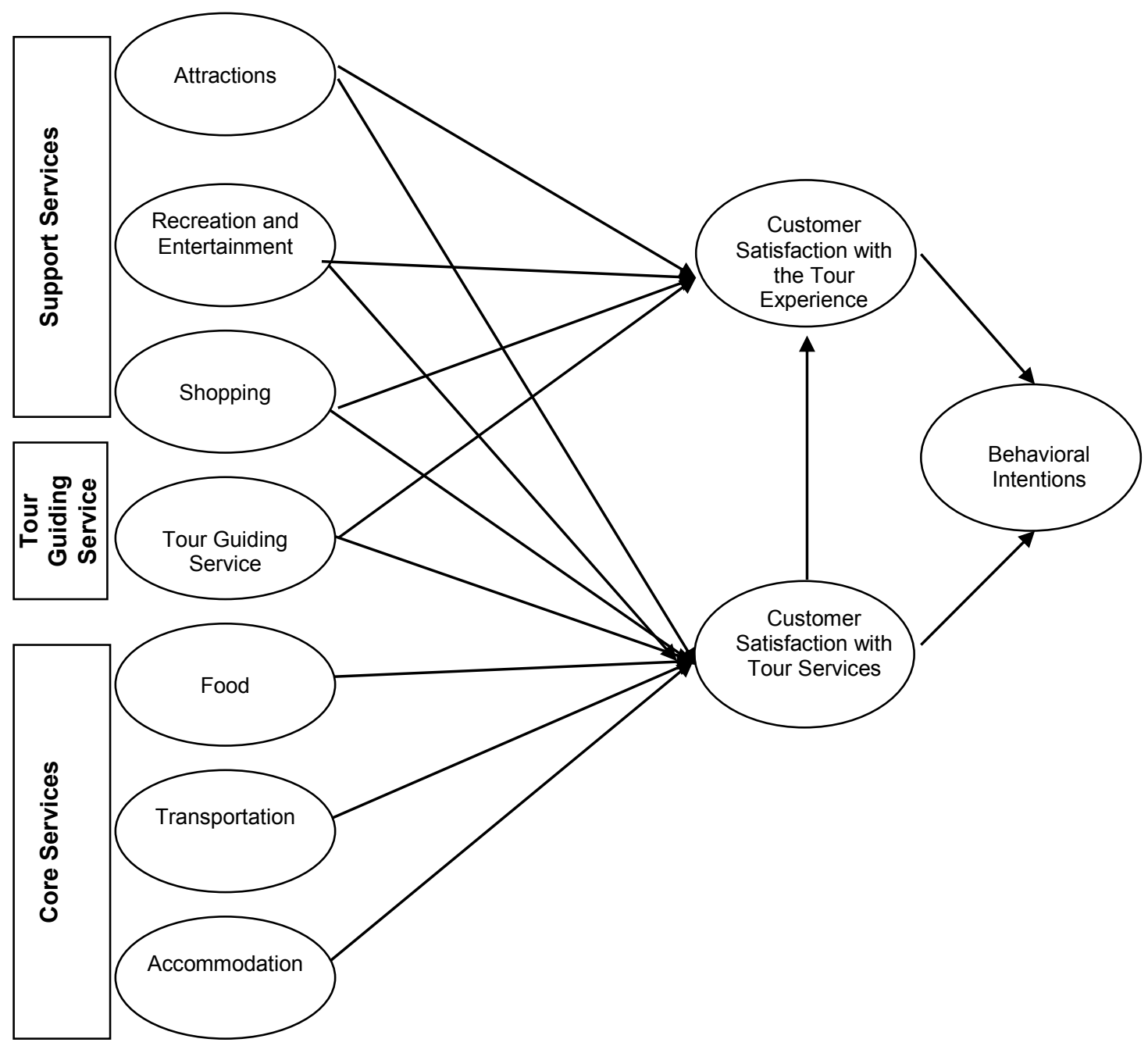


Table 1

Demographic Profiles of Respondents

\begin{tabular}{|c|c|c|c|}
\hline Characteristic & Category & Frequency & Percent $(\%)$ \\
\hline \multirow[t]{2}{*}{ Gender } & Male & 236 & 40.7 \\
\hline & Female & 344 & 59.3 \\
\hline \multirow[t]{2}{*}{ Marital Status } & Married & 439 & 75.7 \\
\hline & Single & 141 & 24.3 \\
\hline \multirow[t]{6}{*}{ Age } & $16-25$ & 96 & 16.6 \\
\hline & $26-35$ & 168 & 29.0 \\
\hline & $36-45$ & 137 & 23.6 \\
\hline & $46-55$ & 105 & 18.1 \\
\hline & $56-65$ & 58 & 10.0 \\
\hline & 66 and over & 16 & 2.8 \\
\hline \multirow[t]{4}{*}{ Education } & Primary school & 11 & 1.9 \\
\hline & Secondary school & 144 & 24.8 \\
\hline & College & 375 & 64.7 \\
\hline & Postgraduate & 50 & 8.6 \\
\hline \multirow{7}{*}{$\begin{array}{l}\text { Region of } \\
\text { Residence }\end{array}$} & Southern & 48 & 8.3 \\
\hline & Eastern & 195 & 33.6 \\
\hline & Northern & 113 & 19.5 \\
\hline & Central & 78 & 13.4 \\
\hline & Southwestern & 58 & 10.0 \\
\hline & Northeastern & 46 & 7.9 \\
\hline & Northwestern & 42 & 7.2 \\
\hline \multirow{7}{*}{$\begin{array}{l}\text { Monthly } \\
\text { Household } \\
\text { Income (RMB) }\end{array}$} & 1,999 or below & 96 & 16.5 \\
\hline & $2,000-3,999$ & 198 & 34.1 \\
\hline & $4,000-5,999$ & 125 & 21.6 \\
\hline & $6,000-7,999$ & 48 & 8.3 \\
\hline & $8,000-9,999$ & 38 & 6.5 \\
\hline & $10,000-11,999$ & 31 & 5.3 \\
\hline & 12,000 or above & 44 & 7.6 \\
\hline \multirow{2}{*}{$\begin{array}{l}\text { Travel } \\
\text { Experience }\end{array}$} & First time in Hong Kong & 419 & 72.2 \\
\hline & Second time or more & 161 & 27.8 \\
\hline
\end{tabular}


Table 2

Confirmatory Factor Analysis of Tour Services Items

\begin{tabular}{|l|l|l|l|}
\hline Component/Item & $\begin{array}{l}\text { Factor } \\
\text { Loading }\end{array}$ & $\begin{array}{l}\text { Composite } \\
\text { Reliability }\end{array}$ & $\begin{array}{l}\text { Variance } \\
\text { Extracted }\end{array}$ \\
\hline Transportation & & .89 & .73 \\
\hline Efficiency of transportation & .89 & & \\
\hline Comfort of transportation & .90 & & \\
\hline Transport staff service attitude & .77 & & .85 \\
\hline Accommodation & & .92 & \\
\hline Efficiency of accommodation services & .90 & & \\
\hline Comfort of accommodation & .95 & & .75 \\
\hline Accommodation staff service attitude & .84 & & \\
\hline Food & & .90 & \\
\hline Efficiency of catering and dining services & .80 & & .74 \\
\hline Quality of food & .90 & & \\
\hline Catering and dining staff service attitude & .90 & & \\
\hline Leisure Activities & & .89 & \\
\hline Variety of attractions & .73 & & \\
\hline $\begin{array}{l}\text { Variety of recreation and entertainment } \\
\text { activities }\end{array}$ & .91 & & \\
\hline $\begin{array}{l}\text { Attractiveness of recreation and } \\
\text { entertainment activities }\end{array}$ & .92 & & \\
\hline Shopping & & .66 \\
\hline Time arrangements for shopping & .81 & & \\
\hline Value for money of products & .91 & & \\
\hline Shop staff service attitude & .71 & & \\
\hline Tour Guiding Service & & .90 & \\
\hline Efficiency of guiding service & .79 & & \\
\hline Tour guide communication skills & .92 & & \\
\hline Tour guide service attitude & & & \\
\hline
\end{tabular}


Table 3

Confirmatory Factor Analysis of Satisfaction and Behavioral Intentions

\begin{tabular}{|c|c|c|c|}
\hline Item/Component & $\begin{array}{l}\text { Factor } \\
\text { Loading }\end{array}$ & $\begin{array}{l}\text { Composite } \\
\text { Reliability }\end{array}$ & $\begin{array}{l}\text { Variance } \\
\text { Extracted }\end{array}$ \\
\hline Satisfaction with Tour Services & & .98 & .93 \\
\hline Dissatisfied/satisfied & .96 & & \\
\hline Displeased/pleased & .97 & & \\
\hline Unfavorable/favorable & .96 & & \\
\hline \multicolumn{4}{|l|}{ Satisfaction with Tour Experience } \\
\hline Seeking & & .92 & .86 \\
\hline The tour has a special meaning for me. & .95 & & \\
\hline I had a "once in a lifetime" experience. & .90 & & \\
\hline Escaping & & .93 & .80 \\
\hline I enjoyed the trip. & .94 & & \\
\hline I had fun. & .94 & & \\
\hline I was totally relaxed. & .81 & & \\
\hline \multicolumn{4}{|l|}{ Behavioral Intentions } \\
\hline Loyalty & & .93 & .88 \\
\hline $\begin{array}{l}\text { I will say positive things about this operator } \\
\text { to other people. }\end{array}$ & .90 & & \\
\hline $\begin{array}{l}\text { I will encourage friends and relatives to } \\
\text { join tours organized by this tour operator. }\end{array}$ & .97 & & \\
\hline Willingness to pay & & .97 & .93 \\
\hline $\begin{array}{l}\text { I will continue to join tours organized by } \\
\text { this operator, even if the prices increase } \\
\text { somewhat. }\end{array}$ & .99 & & \\
\hline $\begin{array}{l}\text { I would join higher priced tours organized } \\
\text { by this operator. }\end{array}$ & .94 & & \\
\hline
\end{tabular}


Figure 2: Tour Service Performance Model

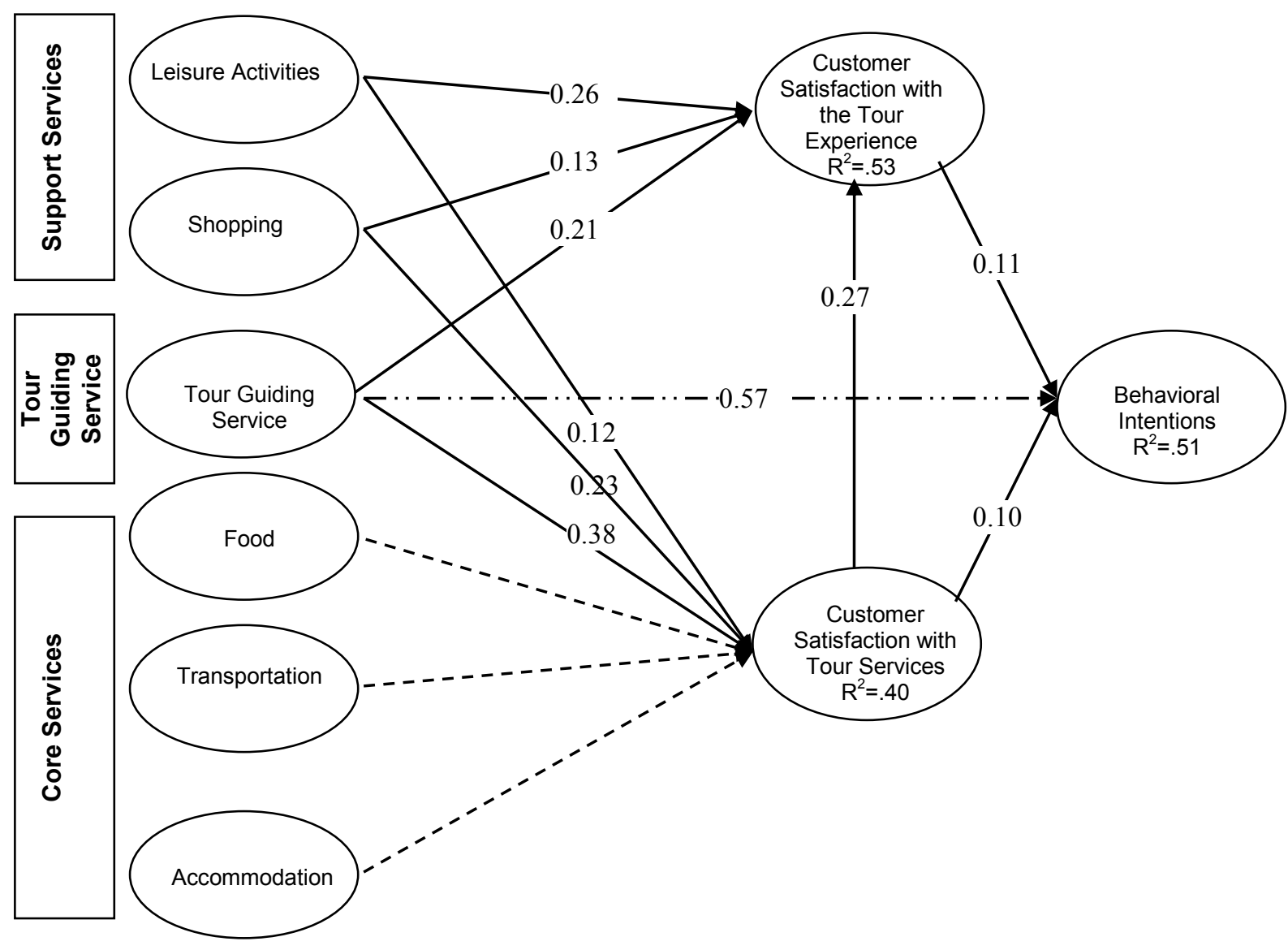

Note:

insignificant at the 0.05 level

relationship not hypothesized in the initial model 